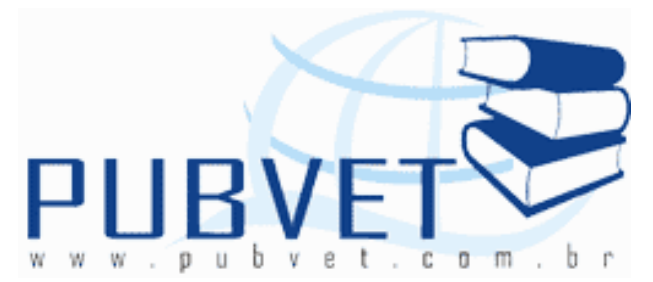

PUBVET, Publicações em Medicina Veterinária e Zootecnia.

\title{
Viabilidade microbiológica do soro sangüíneo autólogo como coadjuvante no tratamento de úlceras de córnea em cães (Canis familiaris, LINNAEUS, 1758)
}

Ana Letícia Bambirra ${ }^{1}$; Arianne Pontes Oriá ${ }^{*}$; Robson Bahia ${ }^{3}$; Francisco de Assis Dórea Neto ${ }^{3}$; Melissa Hanzen Pinna ${ }^{4}$

${ }^{1}$ Residente em Clínica Médica de Pequenos Animais do Hospital Veterinário da UNIME, Lauro de Freitas - BA

${ }^{2}$ Professora Adjunto do Departamento de Patologia e Clínicas da Universidade Federal da Bahia -UFBA, Salvador -BA Escola de Medicina Veterinária, Departamento de Patologia e Clínicas, Av. Ademar de Barros, 500, Ondina. Cep:40170-110 arianneoria@ufba.br

${ }^{3}$ Professor Adjunto UNIME, Lauro de Freitas - BA

${ }^{4}$ Laboratório de Bacterioses do Departamento de Medicina Veterinária Preventiva da Escola de Medicina Veterinária, Universidade Federal da Bahia.

\section{Resumo}

A úlcera de córnea é uma das afecções oculares que mais ocorrem na clínica de pequenos animais. Em seu tratamento, utilizam-se vários medicamentos que têm como objetivo principal interromper a destruição dos tecidos e proporcionar a cicatrização. O soro sangüíneo é bastante utilizado como adjuvante no tratamento de úlceras de córnea, devido ao seu poder epiteliotrópico e por conter vitaminas, imunoglobulinas, substâncias 
anticolagenolíticas e bacteriostáticas. Este trabalho teve como objetivo avaliar o risco de contaminação fúngica e bacteriana do soro canino refrigerado, a ser utilizado no tratamento de úlceras corneais em cães. O sangue foi coletado de sete animais saudáveis, em tubos estéreis e posteriormente centrifugado para a obtenção de alíquotas de soro. Este foi diluído a $50 \%$ em Lacrima ${ }^{\circledR}$ e mantido no refrigerador à temperatura de $4^{\circ} \mathrm{C}$, em frascos conta gotas estéreis, que foram abertos a cada $24 \mathrm{~h}$ e as amostras semeadas em ágar sangue e ágar Sabouraud, para a verificação do crescimento de fungos, por vinte e dois dias e bactérias, por dez dias. Durante a realização deste experimento não houve crescimento de fungos ou bactérias em nenhuma das amostras. Conclui-se que o soro de cão pode ser seguramente utilizado, através de uma coleta e conservação adequadas, por um período de dez dias para contaminação bacteriana e vinte e dois dias para contaminação fúngica.

Palavras-chave: Soro sanguíneo; Úlcera de córnea; Cães

\title{
Microbiologic viability of the autologous serum as an adjuvant in the corneal ulcer management in dogs (Canis familiaris, LINNAEUS, 1758)
}

\begin{abstract}
Corneal ulcer is one of the most commonly ocular affections seen in the small animal practice. Several agents are used for its management with the main purpose of interrupt tissue destruction and promote healing. Blood serum is widely used as an adjuvant in the corneal ulcer management, due to its epitheliotrophic power and also for contains vitamins, immunoglobulins, anticollagenolytic and bacteriostatic properties. This study aimed to evaluate the bacterial and fungal contamination risk of the refrigerated canine serum, to be used in the corneal ulcer management. Blood was collected from seven healthy animals, stored in sterile tubes that were centrifugated afterwards to obtain the serum. This was diluted to $50 \%$ with Lacrima ${ }^{\circledR}$, kept refrigerated at $4^{\circ} \mathrm{C}$ in sterile bottles, which were opened at every 24 hours and samples were sowed in blood agar and Sabouraud, in order to verify fungal growth for
\end{abstract}


BAMBIRRA, A.L. et al. Viabilidade microbiológica do soro sangüíneo autólogo como coadjuvante no tratamento de úlceras de córnea em cães (Canis familiaris, LINNAEUS, 1758). PUBVET, Londrina, V. 5, N. 40, Ed. 187, Art. 1261, 2011.

twenty-two days and bacterial growth, for ten days. During the accomplishment of this study fungal and bacterial growth were not seen in any of the samples. It was concluded that the canine serum can be safely used if adequately collect and preserved for a ten days period bacterial growth and fungal growth for twenty-two days period.

Keywords: Blood serum; Corneal ulcer; Dogs

\section{INTRODUÇÃO}

A ulceração corneal é uma das afecções oculares mais comuns no cão (GELATT, 2003), sendo caracterizada por processos erosivos superficiais ou profundos na córnea, com ruptura ou perda tecidual (STADES et. al ,1999). Segundo Braga et al. (2004) devido a sua localização externa, a córnea esta freqüentemente sujeita a traumas ou processos lesivos como lacerações, perfurações e ulcerações.

O uso de soro sanguíneo autólogo vem sendo relatado com eficácia no tratamento de desordens oculares e na reconstrução da superfície ocular (GOTO et al. 2001). Razani et al. (2006), citaram que o soro sangüíneo apresenta fatores de crescimento, vitaminas, imunoglobulinas, substâncias anticolagenolíticas e bacteriostáticas que podem propiciar um efeito epiteliotrópico para a superfície ocular. Sendo bastante utilizado como adjuvante no tratamento de úlceras de córnea e ceratoconjuntivite seca.

Baerman e Dohlman (1975) já indicavam a utilização do soro sangüíneo durante o tratamento de úlceras corneais, pois este possui ação inibidora de colagenases ou, segundo Hibbits, Hines, Willians (1999), possui ação de antiproteinases, por conter proteínas como a1-antitripsina e a2macroglobulina. A a1-antitripsina está presente na maioria dos fluidos do corpo incluindo o humor aquoso e a lágrima. Sua síntese ocorre no fígado, mas também em monócitos circulantes, macrófagos alveolares, enterócitos e na 
BAMBIRRA, A.L. et al. Viabilidade microbiológica do soro sangüíneo autólogo como coadjuvante no tratamento de úlceras de córnea em cães (Canis familiaris, LINNAEUS, 1758). PUBVET, Londrina, V. 5, N. 40, Ed. 187, Art. 1261, 2011.

córnea humana, tem a função de inibir as proteinases (TWINING et al., 1994). Já a a2-macroglobulina, é um inibidor multifatorial, capaz de inibir a maioria das atividades das enzimas, pertencentes a quatro classes: as proteinases do sangue, as metaloproteinases, as proteinases aspárticas e as thiol proteinases (BORTH, 1992). Está presente em altos níveis no sangue, compreendendo de 8 a $10 \%$ do total de proteínas séricas. Por esta razão a aplicação tópica do soro autógeno (uma ou duas gotas a cada uma ou duas horas) é altamente recomendado no tratamento de úlceras corneais em humanos e animais (BERMAN, 1980).

Essa ação anticolagenolítica ou antiproteinase do soro é importante durante o processo de cicatrização da úlceras de córnea, pois Brooks et al (2003) descreveu que essas proteinases existem normalmente em balanço com inibidores de proteinases, em caso de ceratite ulcerativa ou na própria córnea normal, servindo para prevenir uma excessiva degeneração do tecido. Entretanto em úlceras corneais, a combinação de uma superprodução de certas proteinases destrutivas, tais como a neutrofil elastase, que degrada os colágenos tipo III e IV assim como os componentes da matriz extracelular, juntamente com a diminuição da atividade antiprotease, pode levar a uma rápida degradação de colágeno e de outros componentes da córnea.

Durante a fase de cicatrização, segundo Brown e Hook (1971), as proteases e colagenases são liberadas por células epiteliais, por fibroblastos e leucócitos e agem no sentido de remover células mortas e debris. Entretanto em úlceras contaminadas, por fungos ou bactérias, em especial Pseudomonas spp, estas proteinases e colagenases além de serem liberadas através do processo natural de cicatrização, também são liberadas por estes agentes, fazendo com que haja um processo maior de degradação do colágeno e da matriz extracelular da córnea, complicando a úlcera e podendo levar a perfuração corneal. 
BAMBIRRA, A.L. et al. Viabilidade microbiológica do soro sangüíneo autólogo como coadjuvante no tratamento de úlceras de córnea em cães (Canis familiaris, LINNAEUS, 1758). PUBVET, Londrina, V. 5, N. 40, Ed. 187, Art. 1261, 2011.

Além de conter agentes anticolagenoliticos, Swank e Hosgood (1996) citaram que o soro sanguíneo também contém fatores de crescimento epidermal que facilitam o processo de cicatrização de feridas incluindo a córnea. Fatores do crescimento tópicos foram testados em lesões estromais, e mostram-se úteis para o restabelecimento da integridade tecidual, induzindo cicatrizes discretas. O fator de crescimento derivado de plaquetas, o fator transformador de crescimento e o fator de crescimento epidérmico atuam na proliferação de fibroblastos estromais e, conseqüentemente, estimulam a produção de colágeno (SWANK; HOSGOOD, 1996).

Como os colírios de soro sangüíneo contêm uma elevada quantidade de proteínas, existe um risco significativo de contaminação microbiana. A toxidade de algum preservativo adicionado pode excluir algum efeito benéfico do soro sangüíneo e, por este motivo, deve ser evitado (LAGNADO et al., 2004). Sendo assim, colírios devem ser preparados, sob condições estéreis de forma individual para cada paciente, mas mesmo assim ainda há o risco de contaminação, durante a preparação, estoque e o uso do colírio. Quando usado durante a superfície ocular cirúrgica, ele é normalmente combinado profilaticamente com antibióticos tópicos. No entanto existem relatos de infecções sérias durante o uso do colírio nestas condições (POON et al., 2001).

Brooks (1999), já indicava a importância da coleta de soro fresco a cada três dias, por haver um crescimento de bactérias e isto poder causar um declínio em sua atividade inibitória. Tsubota et al. (1999), observaram que a estabilidade dos componentes do soro tais como fatores de crescimento epidermal (EGF), vitamina $A$ e fator transformador do crescimento beta (TGF$\beta)$, encontraram-se estáveis por um mês no refrigerador $\left(4^{\circ} \mathrm{C}\right)$ e três meses no freezer $\left(-20^{\circ} \mathrm{C}\right)$.

Ranzani et al. (2006), em seu experimento (controle microbiológico do soro eqüino para o tratamento de lesões corneais), onde utilizaram soro sanguíneo 
BAMBIRRA, A.L. et al. Viabilidade microbiológica do soro sangüíneo autólogo como coadjuvante no tratamento de úlceras de córnea em cães (Canis familiaris, LINNAEUS, 1758). PUBVET, Londrina, V. 5, N. 40, Ed. 187, Art. 1261, 2011.

de eqüinos refrigerados por uma semana, concluíram que não houve contaminação do material, sendo considerada viável sua utilização, desde que houvesse uma conservação e coleta adequadas.

Lagnado et al. (2004) salientaram que com o crescente uso do colírio de soro sanguíneo, faz-se importante obter informações sobre a sua esterilidade. Todavia, reportam-se também ao fato do soro conter alguns efeitos bacteriostáticos, assim como lisozimas, proteínas do sistema complemento e Imunoglobulina G ( $\mathrm{IGg})$, não sendo necessário o uso de substâncias bacteriostáticas adicionais. Pelo fato de não se saber ao certo, quantos dias o soro permanece viável sobre refrigeração para a utilização, sem risco de contaminação da lesão ulcerativa na córnea, este trabalho objetivou a avaliação da viabilidade microbiológica do soro sanguíneo canino na diluição de

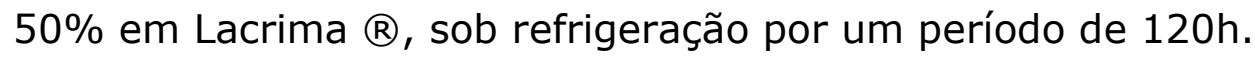

\section{MATERIAL E MÉTODOS}

Foram selecionados 10 animais da espécie canina (Canis familiaris, LINNAUS, 1758) adultos, machos e fêmeas, sem raça definida, saudáveis, fornecidos pelo canil do HOSVET- Hospital Veterinário da UNIME- União Metropolitana de Educação e Cultura, localizada no município de Lauro de Freitas -BA.

Foram utilizados no presente trabalho animais clinicamente sadios triados na rotina hospitalar do HOSVET, sendo os mesmos submetidos a exame clínico detalhado.

Para obtenção do soro sanguíneo, foram coletadas amostras contendo $10 \mathrm{ml}$ de sangue através de venopunção jugular de 10 animais da espécie canina. Amostras sanguíneas foram obtidas de forma asséptica de 7 animais em seringa de $10 \mathrm{ml}$ e agulha $25 \times 7 \mathrm{~mm}$, através de punção na veia jugular, após a etapa de triagem. Em seguida, estas foram resfriadas e transportadas até o laboratório de Patologia Clínica da UNIME, onde foram centrifugadas e o soro 
BAMBIRRA, A.L. et al. Viabilidade microbiológica do soro sangüíneo autólogo como coadjuvante no tratamento de úlceras de córnea em cães (Canis familiaris, LINNAEUS, 1758). PUBVET, Londrina, V. 5, N. 40, Ed. 187, Art. 1261, 2011.

foi estocado em tubos plásticos estéreis, mantidos sob refrigeração. O soro obtido de cada animal originou 14 alíquotas a fim de serem utilizadas para cumprir o objetivo de avaliar a viabilidade microbiológica do mesmo, bem

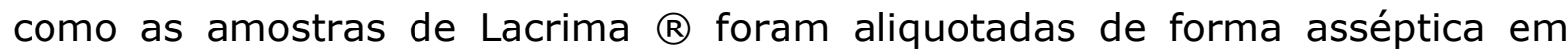
capela de fluxo laminar.

Conceberam-se três grupos designados por GI, GII e GIII:

No GI, composto por sete amostras de soro diluído com Lacrima $®$ na proporção de $50 \%$, sendo uma amostra de cada unidade experimental. Tal concentração foi escolhida por ser esta a recomendada por vários clínicos que militam na rotina oftálmica veterinária, para o tratamento de úlceras de córnea em cães.

No GII, composto por sete amostras de soro sanguíneo, sendo uma amostra de cada unidade experimental.

No GIII, composto por sete amostras de Lacrima ${ }^{\circledR}$.

A cada 24 horas uma alíquota de cada grupo experimental foi semeada em placas agar sangue e mantidas em estufa de incubação por 24 -72horas em temperatura de $37^{\circ} \mathrm{C}$.Enquanto as semeaduras em placas de Agar Sabouraund foram submetidas a incubação em temperatura ambiente, durante 15 dias. As respectivas leituras foram realizadas a cada 24 horas e os dados amontados em planilha de acompanhamento, por um período de até 10 dias para cultivo bacteriano e 22 dias para cultivo fúngico.

\section{RESULTADOS E DISCUSSÃO}

No presente estudo não foi verificado crescimento microbiano nas amostras referentes aos três grupos experimentais. Razani et al. (2006) também não observaram o crescimento de bactérias, quando analisaram amostras de soro eqüino a $20 \%$ por um período de uma semana. Apesar de Poon et al. (2001) relatarem que, quando os colírios são usados durante a superfície ocular 
BAMBIRRA, A.L. et al. Viabilidade microbiológica do soro sangüíneo autólogo como coadjuvante no tratamento de úlceras de córnea em cães (Canis familiaris, LINNAEUS, 1758). PUBVET, Londrina, V. 5, N. 40, Ed. 187, Art. 1261, 2011.

cirúrgica, são normalmente combinados profilaticamente com antibióticos tópicos, pelo que foi observado no presente estudo, não se julga necessária a adição de agentes antimicrobianos no soro, quando da utilização de procedimento com estrita assepsia e anti-sepsia durante a coleta e utilização do soro sanguíneo.

Lagnado et al. (2004) sugeriram que os colírios de soro sangüíneo contêm uma elevada quantidade de proteínas e constituem assim um risco significativo de contaminação microbiana, estes autores também não indicam a adição de preservativos devido à possibilidade de toxidade que estes preservativos podem causar e assim excluir algum efeito benéfico do soro sanguíneo. Poon et al. (2001), citaram que os colírios devem ser preparados, sob condições estéreis de uma forma individual para cada paciente, e mesmo assim ainda há o risco de contaminação, durante a preparação, estoque e o uso do colírio, havendo relatos de sérias infecções durante a utilização do colírio o que sugere que a armazenagem e o uso incorreto deste pode provocar o crescimento de bactérias ou fungos.

É importante lembrar que quando os colírios contendo soros sanguíneo são contaminados com fungos e bactérias, estes patógenos, segundo Xue et al (2003) podem produzir enzimas destruidoras de colágeno, como as metaloproteinases (MMPs) e também induzir as células corneais, os fibroblastos do estroma corneal, e os leucócitos no filme lacrimal e migrados por diapedese a partir do leito vascular, estimulando tais células a liberar citocinas (interleucina IL-1, IL-6, e IL-8).

Sendo assim o soro sanguíneo autólogo constitui-se, segundo Goto et al. (2001) em uma modalidade eficaz de tratamento de desordens oculares e na reconstrução da superfície ocular por este conter fatores de crescimento, vitaminas, imunoglobulinas, substâncias anticolagenolíticas e bacteriostáticas 
BAMBIRRA, A.L. et al. Viabilidade microbiológica do soro sangüíneo autólogo como coadjuvante no tratamento de úlceras de córnea em cães (Canis familiaris, LINNAEUS, 1758). PUBVET, Londrina, V. 5, N. 40, Ed. 187, Art. 1261, 2011.

que podem propiciar um efeito epiteliotrópico para a superfície ocular (RAZANI et al. 2006).

\section{CONCLUSÃO}

O soro sangüíneo de cão diluído ou não a 50\% em Lacrima $®$ pode ser utilizado com segurança, como coadjuvante no tratamento de úlceras de córnea, diante de uma coleta e conservação adequadas, totalizando um período de dez dias para preservação bacteriana e 22 dias para preservação fúngica.

\section{REFERÊNCIAS BIBLIOGRÁFICAS}

BAERMAN M., DOHLMAN C. Collagenase Inhibitors. Arch. Opht. (Paris), v. 35, n. 1. p. 95108. 1975.

BERMAN, M. Collagenase and corneal ulceration. In: Woolley D, Evanson J., editors. Collagenase in normal and phatological connective tissues. Chicester: John Wiley; 1980. p. 140-74.

BORTH, W. a- macroglobulin, a multifunctional binding protein with target characteristics. FASEB journal, v.6,n.7, p. 3345-3353,1992.

BRAGA F.V. A., PIPPI N. L., GOMES K., WEISS M., FLORES F., DALMOLIIN F. , SEVERO D., KRAUSPENHAR L., LEOTTE A. Ceratoplastia com enxerto autógeno lamelar livre de córnea e pediculado de conjuntiva fixados com adesivo de cianocrilato em cães. Ciência Rural, Santa Maria, v.34, n.4, p.1119-1126, jul-ago, 2004.

BROOKS D. E., OLIVER F. J., SCHULTZ G. S., ANDREW S. E., LASSALINE M. E., KALLBERG ME, et al. Duration of in vitro inhibitory activity of equine serum against equine tear film matrix metalloproteinases [abstract 902]. In: Proceedings of the Association for Research in Vision and Ophtalmology. Rockville (MD); Association for Research in Vision and Ophthalmology; 2003. p.36.

BROOKS D. E. Equine ophthalmology. In: Gelatt KN, editor. Veterinary Ophtalmology. $3^{\text {rd }}$ edition. Philadelphia: Lippincott Williams \& Wilkins; 1999. p.1053-116.

BROWN S. I., HOOK C. W., Treatment of corneal destruction with collagenase inhibitors. Trans Am Acad ophtalmol Otolaryngol. v. 75; p.1199-207. 1971

GELATT, K. N. Manual de Oftalmologia veterinária. $1^{\text {a }}$ Ed. São Paulo: Manole, 2003. p. 606

GOTO, E., SHIMURA, S.,SHIMAZAKI, J. Treatment of superior limbic keratoconjutiviyes by application of autologous serum. Cornea. v. 20, p. 807-10. 2001

HIBBITS, K.; HINES, B.; WILLIANS, D. An overview of proteinase inhibitors. J Vet Intern Med. v.13, p. 302-8. 1999 
LAGNADO,R.; KING, A.J.; DONALD, F.; DUA, H. S. A protocol for low contamination risck of autologous serum drops in the manegment of ocular surface disorders. $\mathrm{Br}$. J. Ophtalmol. v. 88; p.464-465. 2004

POON, A. C., GEERTING, G., DART, J.K.G. Autologous serum eyedrops for dry eyes and epithelial defects: clinical and in vitro toxicity studies. $\mathrm{Br}$. J. Oophtalmol. v. 85 , p. 118897. 2001.

RANZANI J.J.T, CREMONINI D. N., BRANDÃO C.V.S., SIQUEIRA A. K., CHIURCIU J. L. V. Controle microbiológico do soro eqüino para o tratamento de lesões corneanas. Arquivo Brasileiro de Medicina Veterinária e Zootecnia. Brazilian Journal of Veterinary and animal sciences. v.58, supl 2, p. 100-113. 2006

STADES, F. C.;BOEVÉ, M. H.; NEUMANN,W.; WYMAN, M. córnea e esclera In: Fundamentos de oftalmologia veterinária. São Paulo: Manole, 1999. p.114-22.

SWANK A., HOSGOOD G., Corneal wound healing and the role of growth factors. The Compendium Small Animal. v. 18 ; n. 9, p. 1007-16. 1996

TWINING, S. S. REgULATION OF PROTEOLYTIC ACTIVITY IN TISSUES. CRIT REV BIOCHEM MOL BIOL. v. 29, p. 315-83. 1994

XUE M, Wakefield D, Willcox M, Lloyd AR, Di Girolamo N, Cole N, et al. Regulation of MMPs and TIMPs by IL-1 $\beta$ during the corneal ulceration and infection. Invest Ophthalmol Vis Sci. v. 44, n. 5, p. 2020-5. 2003 